Dinamika Kesehatan Jurnal Kebidanan dan Keperawatan Vol 10 No. 2 Desember 2019 ( ISSN: 2086-3454 EISSN: 2549-4058)

url: http://ojs.dinamikakesehatan.unism.ac.id DOI: https://doi.org/10.33859/dksm.v10i2

Efektifitas Teknik Akupuntur Untuk Menurunkan Intensitas Nyeri Post-partum Pasca Sectio Cesarea Di Rumah Sakit Mitra Sejati Kota Medan

\title{
Efektifitas Teknik Akupuntur Untuk Menurunkan Intensitas Nyeri Post-partum Pasca Sectio Cesarea Di Rumah Sakit Mitra Sejati Kota Medan
}

\author{
Siska Suci Triana Ginting ${ }^{1}$, Lisa Putri Damanik ${ }^{2}$ \\ ${ }^{1,2}$ Sekolah Tinggi Ilmu Kesehatan Mitra Husada Medan \\ Email: sergiojayden@yahoo.co.id
}

DOI: https://doi.org/10.33859/dksm.v10i2.518

\begin{abstract}
Abstrak
Latar belakang:Persalinan sesar memang dapat memudahkan proses persalinan sehingga banyak ibu hamil yang lebih memilih jalur ini meski sebenarnya mereka bisa melahirkan secara normal. faktanya, angka kematian di seksio sesarea adalah 40-80 per 100.000 kelahiran hidup. Angka ini menunjukkan risiko 25x lebih besar daripada persalinan melalui persalinan pervaginam. Bahkan untuk satu kasus karena infeksi memiliki angka 80x lebih tinggi dari persalinan pervaginam.

Tujuan: penelitian ini bertujuan untuk mengurangi kasus operasi caesar yang dapat menyelamatkan nyawa bagi ibu dan bayi.Target spesifik yang dilakukan dalam penelitian ini berfokus pada pasien post-partum dengan sectio caesarea yang sering mengalami gangguan seperti seringnya resistensi (mati rasa), nyeri tulang belakang, atau nyeri di perut. Kebanyakan pasien post sectio cesarea khawatir tentang keluhan yang ditangani, karena semua keluhan ini pada dasarnya dapat diantisipasi dan diatasi.

Metode: menggunakan metode observasional, dengan pendekatan cross sectional. Penelitian ini dilakukan di Rumah Sakit Mitra Sejati Medan tahun 2018. Populasi dalam penelitian ini adalah semua ibu post-partum sesar yang berada di Rumah Sakit Mitra Sejati Medan 2018 dengan desain Pra-eksperimental Sementara desain penelitian ini menggunakan One-Group pre-group. desain post-test, karena pra-eksperimental tidak memerlukan kontrol.

Hasil: pada penelitian ini terlihat efektifitas terapi akupuntur untuk menurunkan intensitas nyeri postpartum pasca section caseria di rumah sakit Mitra Sejati kota Medan tahun 2018 lebih sedikit mengalami rasa nyeri dibandingkan kelompok kontrol yang hanya dilakukan perawatan luka biasa

Simpulan: Ibu yang dijadikan kelompok kontrol merasakan nyeri kuat,Ibu post-partum yang dilakukan intervensi terapi akupuntur mengalami penurunan rasa nyeri, terdapat pengaruh pemanfaatan terapi akupuntur terhadap penurunan rasa nyeri pada ibu post-partum SC $(\mathrm{P}=0,000 ;<0,05)$
\end{abstract}

Kata kunci: Efektifitas, Teknik Akupunktur, Intensitas Nyeri Pasca Partum, Sektio Pasca Sesar 
Background: Cesarean delivery can indeed facilitate the labor process so that many pregnant women who prefer this route even though they can actually give birth normally. in fact, the mortality rate in cesarean section is 40-80 per 100,000 live births. This figure shows a 25x greater risk than labor through vaginal delivery. Even for one case due to infection it has a rate 80x higher than vaginal delivery.

Objective: this study aims to reduce the cases of cesarean section that can save lives for both mother and baby. The specific target undertaken in this study focuses on post-partum patients with sectio caesarea who often experience disorders such as frequent resistance (numbness), spinal pain, or abdominal pain. Most post sectio cesarea patients are worried about complaints being addressed, because all these complaints can basically be anticipated and overcome.

Method: using observational method, with cross sectional approach. This research was conducted at Medan Mitra Sejati Hospital in 2018. The population in this study were all post-partum cesarean mothers who were in the Medan Sejati Hospital 2018 with Pre-experimental designs. While the design of this study used One-Group pre-group. post-test design, because pre-experimental does not require control.

Results: in this study the effectiveness of acupuncture therapy to reduce the intensity of post-partum postcasum pain in Mitra Sejati Hospital in Medan city in 2018 experienced less pain compared to the control group that only performed normal wound care.

Conclusion: Mothers who were used as a control group felt strong pain, post-partum mothers who did acupuncture therapy intervention experienced a decrease in pain, there was an influence of the use of acupuncture therapy to decrease pain in post-partum SC mothers $(P=0,000 ;<0.05)$

Keywords: Effectiveness, Acupuncture Techniques, Post-Partum Pain Intensity, Post-Caesarean sectio

\section{PENDAHULUAN}

Sejauh ini bentuk-bentuk pelayanan

kesehatan yang dikenal masyarakat dalam sistem

pelayanan kesehatan adalah pelayanan rawat inap

dan rawat jalan. Pada sisi lain banyak anggota masyarakat yang menderita sakit karena berbagai

pertimbangan terpaksa dirawat di rumah dan tidak

dirawat inap di institusi pelayanan kesehatan.

Faktor-faktor yang mendorong

perkembangan perawatan kesehatan di rumah

adalah:

Kasus-kasus penyakit terminal dianggap tidak efektif dan tidak efisien lagi apabila dirawat di institusi pelayanan kesehatan. Misalnya pasien kanker stadium akhir yang secara medis belum ada upaya yang dapat dilakukan untuk mencapai kesembuhan,

Keterbatasan masyarakat untuk membiayai pelayanan kesehatan pada kasus-kasus penyakit degeneratif yang memerlukan perawatan yang relatif lama. Dengan demikian berdampak pada makin meningkatnya kasus-kasus yang memerlukan tindak lanjut keperawatan di rumah. Misalnya pasien pasca stroke yang mengalami komplikasi kelumpuhan dan 
Dinamika Kesehatan Jurnal Kebidanan dan Keperawatan Vol 10 No. 2 Desember 2019 ( ISSN: 2086-3454 EISSN: 2549-4058)

url: http://ojs.dinamikakesehatan.unism.ac.id DOI: https://doi.org/10.33859/dksm.v10i2

Efektifitas Teknik Akupuntur Untuk Menurunkan Intensitas Nyeri Post-partum Pasca Sectio Cesarea

Di Rumah Sakit Mitra Sejati Kota Medan

memerlukan pelayanan rehabilitasi yang

membutuhkan waktu relatif lama.

Perawatan Kesehatan di rumah bukanlah merupakan sebuah konsep baru dalam sistem pelayanan kesehatan, khususnya pada praktek keperawatan komunitas. Hal ini sudah dikembangkan sejak tahun 1859 yang pada saat itu Willian Rathbone of Liverpool, England dan juga Florence Nightingale melakukan perawatan kesehatan di rumah dengan memberikan pengobatan kepada pasien (masyarakat) yang mengalami sakit terutama terutama mereka dengan status sosial ekonomi rendah, kondisi sanitasi, kebersihan diri dan lingkungan, dan gizi buruk sehingga beresiko tinggi terhadap berbagai jenis penyakit infeksi yang umum ditemukan di masyarakat.

Dengan hasil yang diperoleh maka, akan menurunkan angka kematian dan infeksi pada ibu nifas. Hasil kajian Depkes RI tahun 2000 diperoleh hasil: $97,7 \%$ menyatakan perlu dikembangkan pelayanan kesehatan di rumah, 87,3\% mengatakan bahwa perlu standarisasi tenaga, sarana dan pelayanan, serta $91,9 \%$ menyatakan pengelola keperawatan kesehatan di rumah memerlukan ijin oprasional.Sebagian besar pasien-pasien post sectio cesarea merasa khawatir akan keluhan diata, karena semua keluhan tersebut pada dasarnya bisa diantisipasi dan diatasi. Tentu saja semua masalah tersebut dapat diatasi dengan perawatan dan penanganannya tepat dan intensif. Pelayanan One Day Care menghindarkan pasien dari terjadinya infeksi nosokomial karena pasien tidak perlu di rawat lama di rumah sakit sehingga dapat menekan biaya yang dikeluarkan oleh pasien. Selain One Day Care, di Indonesia juga di kenal Home Care. (Jie, 2015)

Pelayanan kesehatan di rumah merupakan program yang sudah ada dan perlu dikembangkan, karena telah menjadi kebutuhan masyarakat, Salah satu bentuk pelayanan kesehatan yang sesuai dan memasyarakat serta menyentuh kebutuhan masyarakat yakni melalui pelayanan terapi komplementer yaitu akupuntur.(Ace, 2016)

Sejauh ini bentuk-bentuk pelayanan kesehatan yang dikenal masyarakat dalam sistem pelayanan kesehatan adalah pelayanan rawat inap dan rawat jalan. Pada sisi lain banyak anggota masyarakat yang menderita sakit karena berbagai pertimbangan terpaksa dirawat di rumah dan tidak dirawat inap di institusi pelayanan kesehatan. Faktor-faktor yang mendorong perkembangan perawatan kesehatan di rumah adalah Kasus-kasus 
Dinamika Kesehatan Jurnal Kebidanan dan Keperawatan Vol 10 No. 2 Desember 2019 ( ISSN: 2086-3454 EISSN: 2549-4058)

url: http://ojs.dinamikakesehatan.unism.ac.id DOI: https://doi.org/10.33859/dksm.v10i2

Efektifitas Teknik Akupuntur Untuk Menurunkan Intensitas Nyeri Post-partum Pasca Sectio Cesarea

Di Rumah Sakit Mitra Sejati Kota Medan

penyakit terminal dianggap tidak efektif dan

tidak efisien lagi apabila dirawat di institusi

pelayanan kesehatan. Misalnya pasien kanker

stadium akhir yang secara medis belum ada

upaya yang dapat dilakukan untuk mencapai

kesembuhan.

Banyak orang merasakan bahwa dirawat inap di institusi pelayanan kesehatan membatasi kehidupan manusia, karena seseorang tidak dapat menikmati kehidupan secara optimal karena terikat dengan aturanaturan yang ditetapkan, Lingkungan di rumah ternyata dirasakan lebih nyaman bagi sebagian pasien dibandingkan dengan perawatan di rumah sakit, sehingga dapat mempercepat kesembuhan (Depkes, 2013).

Hasil kajian Depkes RI tahun 2000 diperoleh hasil : 97,7 \% menyatakan perlu dikembangkan pelayanan kesehatan di rumah, 87,3 \% mengatakan bahwa perlu standarisasi tenaga, sarana dan pelayanan, serta 91,9\% menyatakan pengelola keperawatan kesehatan di rumah memerlukan ijin oprasional.

One Day Care pelayanan atau pelayanan rawat sehari yang merupakan perawatan dalam jangka waktu pendek (relatif singkat), yaitu 1 hari atau 24 jam. Menurut penelitian hampir $70 \%$ rumah sakit Indonesia menerapkan sistem one day care. Pelayanan One Day Care menghindarkan pasien dari terjadinya infeksi nosokomial karena pasien tidak perlu di rawat lama di rumah sakit sehingga dapat menekan biaya yang dikeluarkan oleh pasien. Selain One Day Care, di Indonesia juga di kenal Home Care. Home Care adalah suatu pelayanan yang bertujuan untuk meningkatkan, mempertahankan atau memaksimalkn tingkat kemandirian dan meminimalkan akibat dari penyakit.

Berdasarkan hasil pengkajian bahwa banyak masyarakat dan pengelola program kesehatan menyatakan perlu dikembangkan pelayanan perawatan kesehatan terapo komplementer Teknik Akupuntur pada ibu nifas Post Sectio Cesarea.

\section{METODE dan BAHAN}

Penelitian ini menggunakan penelitian ekperimen dengan rancangan penelitian Preeksperimental design Sedangkan design rancangan penelitian ini menggunakan One- 
Dinamika Kesehatan Jurnal Kebidanan dan Keperawatan Vol 10 No. 2 Desember 2019 ( ISSN: 2086-3454 EISSN: 2549-4058)

url: http://ojs.dinamikakesehatan.unism.ac.id DOI: https://doi.org/10.33859/dksm.v10i2

Efektifitas Teknik Akupuntur Untuk Menurunkan Intensitas Nyeri Post-partum Pasca Sectio Cesarea

Di Rumah Sakit Mitra Sejati Kota Medan

Group pre-post test design, karena pre-

eksperimental tidak mensyaratkan adanya

control.

Data ini diperoleh secara langsung dengan cara observasi dan melakukan pengukuran metode pre dan postest. Teknik pengukuran penurunan intensitas nyeri dalam penelitian ini adalah peneliti mendatangi ibu post operasi SectioCaesarea hari pertama dan melakukan ovservasi keefektifan Teknik Akupuntur terhadap nyeri post section.

\section{PEMBAHASAN}

pada penelitian ini terlihat efektifitas terapi akupuntur untuk menurunkan intensitas nyeri post-partum pasca section caseria di rumah sakit Mitra Sejati kota Medan tahun 2018 lebih sedikit mengalami rasa nyeri dibandingkan kelompok control yang hanya dilakukan perawatan luka biasa. Sejalan dengan penelitian (Ari, 2016) yang berjudul pemanfaatan teknik akupuntur untuk menurunkan intensitas nyeri post section caseria sehingga ada perbedaan intensitas nyeri pasca sc sesudah pemberian terapi dengan nilai $t$ hitung sebesar 9,000 (t hitung $>$ 2,016) dan Asymp. sig (2-tailed) sebesar 0,001 $(p<0,05)$
Secara fisik tindakan SC menyebabkan

nyeri pada abdomen .Nyeri yang berasal dari luka operasi (Arwani,dkk 2012). Persalinan SC memiliki nyeri lebuh tinggi sekitar 27,3 \% sdibandingkan dengan persalinan normal yang hanya sekitar 9\%. Umumnya, nyeri yang dirasakan selama beberapa hari. Rasa nyeri meningkat pada hari pertama post operasi SC. secara psikologi tindakan SC berdampak terhadap rasa takut dan cemas terhadap nyeri yang dirasakan setelah analgetik hilang. Selain itu juga memberikan dampak negative terhadap konsep diri ibu. Karena ibu kehilangan pengalaman melahirkan secara normal dan harga diri yang terkait pada perubahan citra tubuh akibat tindakan oprasi(Akbar,dkk, 2014).

\section{KESIMPULAN DAN SARAN}

1. Ibu yang dijadikan kelompok control merasakan nyeri kuat

2. Ibu post-partum yang dilakukan intervensi terapi akupuntur mengalami penurunan rasa nyeri

3. Ada pengaruh pemanfaatan terapi akupuntur terhadap penurunan rasa nyeri pada ibu postpartum SC $(\mathrm{P}=0,000 ;<0,05)$

4. Diharapkan agar bekerja sama dengan Dinas 
Kesehatan dalam memberikan terapi

akupuntur untuk pengurangan rasa nyeri dan

melancarkan ASI pada ibu nifas dan perlunya

pemberian informasi yang cukup bagi ibu

nifas tentang terapi akupuntur.

\section{DAFTAR PUSTAKA}

Akupunktur Untuk pengobatan. 2008. http://fkuii.org/tiki read_article.php? articleId $=95 \&$ comzone $=$ show

BoDarmojo, Martono, H. (2010). Text book of generiatic: Health science in elderly.FK UI. Jakarta.

Castle, N. G., \& Ferguson, J. C. (2010). What is nursing home quality and how is it measured? The Gerontologist, 50(4), 426-442.

Dewi, Kartika. 2011. AkupunkturSebagai Terapi Pada FrozenShoulder. JKM Vol.11/No.1/Juli2011, hal 92-101,ISSN 14119641

Dharmojono. 2001. Menghayati Teori dan Praktek Akupunktur dan Moksibusi. Jilid 1. Jakarta: Trubus Agriwidjaya

Karsten P, Kucukdeveci AA, Tennant A. The Use of The Visual Analogue Scale (VAS) in Rehabilitation Outcomes. J Rehabil Med. 2012

Oetomo. 1980. Seni Akupunktur Modern. Jakarta: Bhratara Karya Aksara.

Sim Kie Jie. 2008. Ilmu Terapi Akupunktur. Jilid 1. Singapore: TCM Publication. . 1997. Dasar Teori Ilmu Akupunktur. Jakarta: Gramedia Widiasarana Indonesia.

Yudiyanta, Novita. (2015). Assessment Nyeri. Patient Comfort Assessment Guide 